\title{
Cacao Yield in Different Planting Densities
}

\author{
Carlos Alberto Spaggiari Souza ${ }^{1}$, Luiz Antônio dos Santos Dias ${ }^{2 *}$, Marco Antonio Galeas \\ Aguilar $^{1}$, Sabrina Sonegheti ${ }^{1}$, Jéferson Oliveira ${ }^{1}$ and Jorge Luiz Andrade Costa ${ }^{2}$ \\ ${ }^{1}$ Comissão Executiva do Plano da Lavoura Cacaueira; Estação Experimental 'Filogônio Peixoto'; 27200-000; \\ Linhares - ES - Brasil. ${ }^{2}$ Departamento de Fitotecnia; Universidade Federal de Viçosa; 36571-000; Viçosa - MG - \\ Brasil
}

\begin{abstract}
The effect of six planting densities on cacao yield of a commercial hybrid mixture as well as the interaction of planting densities with the years were investigated. Crop data collected over a 14-year period (1977-1990) showed that it was possible to optimise the regional cacao yields by implementing high planting densities (2500 and 1736 trees $\left.\mathrm{ha}^{-1}\right)$. This was however only true for the first half of the crop period. In the second half, low planting density (1059 trees $\mathrm{ha}^{-1}$ ) attained the best yields. This change in the ranking of planting densities over the years confirmed the presence of density-year interaction. Alternatives to achieve high productivity in high planting density systems were presented and discussed.
\end{abstract}

Key words: Density-year interaction, high productivity and Theobroma cacao L

\section{INTRODUCTION}

Cacao (Theobroma cacao L.) cultivation in the state of Espírito Santo, Brazil, dates back to the $19^{\text {th }}$ century. Crops were established at low planting densities, i.e., 600-700 trees $\mathrm{ha}^{-1}$. Since the mid $20^{\text {th }}$ century, however, all the commercial stands were established in $3.0 \times 3.0 \mathrm{~m}$ spacing (1111 trees $\mathrm{ha}^{-1}$ ), based on the model production system of the cacao region in Bahia. These days, the search for high productivity and the appearance of witches' broom disease have highlighted the need for changes in the production system, especially regarding the planting density. Witches' broom caused by the fungus Crinipellis perniciosa (Stahel) Singer is the main disease in the cacao regions of Brazil and northern South America. It accounts for an average cacao yield loss of $30 \%$ and can attain $90 \%$ in areas without control (Luz et al., 1997). The pathogen $C$. perniciosa causes an overdevelopment of the meristematic tissues which leads to hypertrophic growth, conferring the shoots the characteristic broom-like appearance. Fruits and seeds are also infected by the fungus, subjecting them to necrosis and loss of the commercial value. Disease control measures are sanitation pruning, the use of resistant genotypes and chemical control. Regionally, there is currently a growing interest for the establishment of cacao plantations with high-yielding clones at high planting densities. This production system has already proved successful in Indonesia (Wood and Lass, 1985), Malaysia (Lockwood and Pang, 1996) and now also in the Bahia cacao region (Luz et al., 1997). Productive witches' broom-tolerant clones are being used in the latter. In view of the new challenges, high planting densities tend to be

\footnotetext{
*Author for correspondence: lasdias@ufv.br
} 
adopted in the regional cacao cultivation. For a detailed review on genetic improvement of cacao see Dias (2004).

In the past, cacao farmers in Ghana and Nigeria also planted cacao at high densities, spacing trees 1.5 to $2.4 \mathrm{~m}$ apart. However, high planting density has a considerable effect on the yield, which is closely related with the age. Only during the first years, high planting densities seem to result in high crop yields (Freeman, 1929; Kowal, 1959), reflecting a significant planting density-clone interaction (Lockwood and Pang, 1996). Dias et al. (2000) further showed that high planting density favours both high yields and witches' broom incidence. The present study aimed at an evaluation of the cacao yields of a hybrid mixture at six planting densities as well as the interaction of planting densities with the years.

\section{MATERIALS AND METHODS}

\section{Plant material}

The trial was set up in October 1971 at the Estação Experimental 'Filogônio Peixoto' (ESFIP), which is part of the Experimental Stations Net of the Comissão Executiva do Plano da Lavoura Cacaueira (CEPLAC). ESFIP is located in Linhares, Espírito Santo state, Brazil (lat $19^{\circ} 23^{\prime}$ $\mathrm{S}$, long $40^{\circ} 01^{\prime} \mathrm{W}$, and alt $28 \mathrm{~m}$ asl), $135 \mathrm{~km}$ from Vitória, the capital of the State, northwards along the BR-101. Climatic conditions there are similar to those of the Brazilian cacao regions. The hot humid tropical climate (Köppen Cwa climate type) is characterized by $1200 \mathrm{~mm}$ annual rainfall, concentrated from November to March (72\%) with a dry period between April and August. The mean annual relative air humidity is over $80 \%$ and the mean annual temperature $23.5{ }^{\circ} \mathrm{C}$. The soil is a fluvic neosoil of average natural fertility.

The genetic material used consisted of a mixture of four hybrids (Catongo x UF 613; Catongo x UF 667; Catongo x IMC 67, and Catongo x SCA 06) produced by controlled pollination from the seed orchards of CEPLAC. Due to the presence of several incompatible alleles in some parental clones of the hybrids, a commercial hybrid mixture is distributed to cacao farmers, often consisting of four or more bi-clonal hybrids. As temporary shade, bananas (Musa spp.) were planted in the same density as the cacao trees. The coral tree (Erythrina glauca) was planted in $24 \mathrm{x}$
$24 \mathrm{~m}$ spacing as permanent shade. The prescribed crop management practices were accomplished annually, except for the fertilization. The trial was arranged in a randomized complete block design with four replications and plots of $2304 \mathrm{~m}^{2}$. Controlled harvesting began in 1977 and was repeated monthly until December 1990, when the trial ended. However, due to a manpower bottleneck only mean data were obtained from each treatment until 1979. There were six treatments representing different planting densities, as described below:

1. 2500 cacao trees per hectare $(2.0 \times 2.0 \mathrm{~m})$

2. 1736 cacao trees per hectare $(2.4 \times 2.4 \mathrm{~m})$

3. 1111 cacao trees per hectare $(3.0 \times 3.0 \mathrm{~m})$ (used as a standard of conventional planting density)

4. 1962 cacao trees per hectare $(3.0 \times 3.0 \mathrm{~m}$; with one tree in the diagonal cross)

5. 1059 cacao trees per hectare $(4.0 \times 4.0 \mathrm{~m})$

6. 625 cacao trees per hectare $(4.0 \times 4.0 \mathrm{~m}$; with one tree in the diagonal cross)

\section{Statistical procedures}

The yield component data evaluated per plot were the total number of healthy fruits (TNF) and the wet (WSW) and dry seed weight (DSW). For data means from 1977 to 1979 , only WSW and DSW were evaluated and presented in a diagram. Analyses of variance for split plots in time were performed for yield component data from 1980 onwards compiled during 11 years (1980-90). These analyses allowed an investigation of the plant density $\mathrm{x}$ year interaction.

Initially, the split-plot in time analysis (Steel and Torrie, 1980) was performed according to Dias et al. (1998), so the planting densities were allocated to the plots and the years to the sub-plots, being both fixed effects. Next, analyses of variance with repeated measures were performed on SAS software (SAS Institute, 1989). The SAS command repeated was used in GLM procedures for repeated-measures analysis to test the covariance structure of repeated measures in order to validate the traditional split-plot in time analysis. The use of this command requires the input of the repeated factor in time, in this case, the year. The test for sphericity known as Mauchly's criterion of the error covariance matrix checked for the H-F condition, with an approximated chi-square test for orthogonal 
contrasts, i.e., for the presence or absence of zero covariance (Dias et al., 2001). To broaden the study, the 11-year period was split in two [pre(1980-85) and post- (1986-90) climax] related to the cacao yield climax, to find out at which point the climax and the increase of competition among trees could alter the cacao trees' performance at different planting densities. For both the climax periods, the split-plot in time and repeatedmeasures analyses were also performed (data not shown).

Following the analysis of variance procedures, differences between plant density means were compared by the Tukey test at a probability level of $\mathrm{P}<0.05$. To compare all density means with the standard (1111 cacao trees $\mathrm{ha}^{-1}$ or $3.0 \times 3.0 \mathrm{~m}$ ), Dunnett test (Steel and Torrie, 1980) was applied at the same probability level.

\section{RESULTS}

The data means in Fig. 1 seemed to show a superior performance of the cacao hybrid mixture at high planting densities, i.e., $2500(2.0 \times 2.0 \mathrm{~m})$ and $1736(2.4 \times 2.4 \mathrm{~m})$ cacao trees per hectare. This was reinforced in 1978, a good year for cacao yield. Fig. 1 further showed an absence of planting density $\mathrm{x}$ year interaction, since no alteration in the performance was observed over the three years.

The split-plot in time variance analyses revealed non-significant differences among the planting densities for all the yield components when analysing the entire 11-year period. Conversely, highly significant $(\mathrm{P}<0.01)$ differences among the years were shown for all of them. The coefficients of variation ranged from $17.2 \%$ for TNF to $18.2 \%$ for DSW, comparable to those obtained in cacao trials. Highly significant $(\mathrm{P}<0.01)$ density-year interaction was detected. This means that plant density and years were not independent factors for all the yield components studied in the advanced ages (Tables 1, 2 and 3).

In order to determine the extent of validity of these univariate tests for year and plant density $\mathrm{x}$ year interaction, it was necessary to reanalyze data as repeated-measures. The chi-square values for 54 degrees of freedom being significant at $\mathrm{P}<0.0001$ for all yield components, the validity of the F-test for planting density $\mathrm{x}$ year interaction becomes doubtful, bearing in mind that the chi-square test examines the hypothesis that univariate F-tests are valid. Certainly, the $\mathrm{P}$ values obtained with the split-plot in time analysis were very small $(\mathrm{P}>\mathrm{F}=0.0001$, Tables 1, 2 and 3).

When the yield averages of the hybrid mixture obtained in the different densities were compared with the standard density, i.e., 1111 cacao trees $\mathrm{ha}^{-1}$ or $3.0 \times 3.0 \mathrm{~m}$, no differences were observed for any of the evaluated yield components (Tables 1,2 and 3). Highly significant $(\mathrm{P}<0.01)$ differences were however observed in the postclimax period for all yield components when the 11-year period was split in two (Table 4).

\section{DISCUSSION}

The superior performance of high-density treatments during the first half of the study period (1977-85) of the trial focused on the first three yield components revealed that high planting densities (2500 and 1736 trees ha ${ }^{-1}$ ) would maximise yields in this region. However, since high density plantations (2500 cacao trees $\mathrm{ha}^{-1}$ ) presented higher witches' broom incidence, as stated by Dias et al. (2000), yields might start declining rapidly thereafter. This could be ascribed to the fact that larger, older trees have more meristematic tissue, favoring both the inoculum production and dissemination. Increase in disease intensity with age was also observed in Ouro Preto do Oeste, Rondônia state, Brazil (Laker and Mota, 1990).

The superior performance in high densities in the first harvest years corroborateed results of other studies (Freeman, 1929; Kowal, 1959). On the other hand, the high planting density favoured the disease incidence. This suggests that despite high density plantations might initially maximise the cacao yield in the region, the damage done by $C$. perniciosa, especially to fruits, could aggravate as the trees age. It has already been noted that Crinipellis causes uncommonly high fruit losses in Rondônia state due to vegetative infection.

It is necessary to emphasise, however, that the continuity of the trial led to a change in results after attaining the mature tree yield period, also called climax age, which was achieved from the $8^{\text {th }}$ to the $10^{\text {th }}$ year of plantation according to Dias et al. (2003b). To a certain extent, this had already been expected. One would expect that the competition among cacao trees would increase with the trees' ageing, favouring low-density 
treatments and reducing the performance of the trees under high density, as it was the case. The expectation regarding witches' broom incidence would be the same. In Trinidad, Freeman (1929) observed small differences in yield per tree up to the tenth year, but thereafter wide planting was associated with higher yields; fifteen-year-old trees planted at $18 \times 18$ feet at produced approximately twice the yield of those at $12 \times 12$ feet.
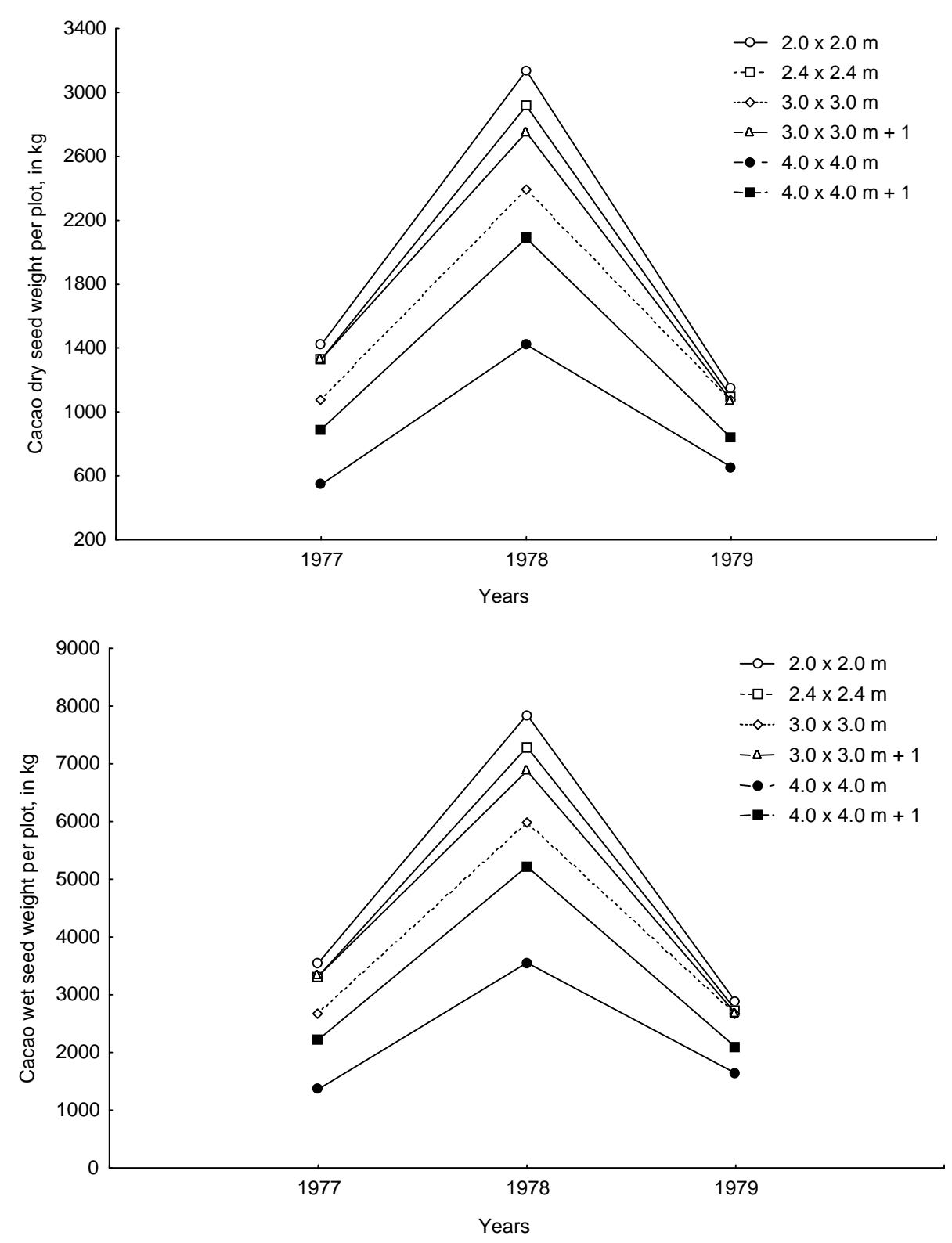

Figure 1 - Performance of a cacao hybrid mixture evaluated in six planting densities (1977-79). 
According to Dias et al. (2000), the adoption of high density plantations requires short genotypes of superior performance. In physiological terms, it is to be expected that dwarf cacao genotypes at high planting density combine good light penetration with vigour and precocity. This calls for the evaluation of different cocoa genotypes at different planting densities. In fact, the presence of clones $\mathrm{x}$ densities interaction has been observed (Lockwood and Pang, 1996). Since cloning by grafting - a technique which is widely used in several cocoa-producing countries - leads to dwarf plant stature, it will play an important role in this context. In Brazil, the commercial use of clones began in 1957, in the counties Linhares, ES and Juçari, BA, with not very promising results. Now cloning is already being put into practice (Luz et al., 1997). However, this new production system demands a basic knowledge on research and crop management at a high technological level from the growers (Dias and Kageyama, 1998; Dias et al., 2000; Dias et al., 2003a). Presently, both the conditions are rarely fulfilled in cacao farming. The existence of pathogenic races different from C. perniciosa (Laker, 1990) along with the evidence of a differential behaviour of cacao clones to infection by these races (Wheeler and Mepsted, 1982) lead to a weakening of witches'- broom resistance as the cacao trees age. The degree of complexity of this matter was discussed by Dias et al. (2000).

In summary, where witche's broom was absent the producer could explore the high planting density during the first years of yield, until the climax age, when the trees surpluses should be eliminated. On the other hand, agroforest systems as suggested by Dias et al. (2000) represent quite satisfactory alternatives to high density planting in regions where witche's broom occurs. In this case, cacao would not be planted in monocrop but rather combined with forest species and fruit trees of economic value. Although yields are lower since the plantation density in these systems is generally reduced (usually 400 cacao trees $\mathrm{ha}^{-1}$ when combined with rubber tree or 1111 cacao trees $\mathrm{ha}^{-1}$ combined with forest species), the income loss can be offset by the yield of the secondary crop. In this system, producers are less vulnerable to price drops of either of the products. On the other hand, witches' broom incidence in cacao trees is lower in low-density plantations, which reflects a more balanced cultivation, with characteristics of selfsustainability. Ongoing experiences with cacao trees combined with other crops in Rondônia are promising.

Table 1 - Analysis of variance with repeated measures for total number of healthy fruits (TNF) assessed in a cacao hybrid mixture evaluated in six planting densities (1980-90).

\begin{tabular}{|c|c|c|c|c|c|c|}
\hline \multirow[b]{2}{*}{ Sources of variation } & \multirow[b]{2}{*}{ df } & \multirow[b]{2}{*}{$\mathrm{F}$} & \multicolumn{4}{|c|}{ P value } \\
\hline & & & (univariate F) & (G-G adjustment) & (H-F condition) & (multivariate F) \\
\hline Block & 3 & & & & & \\
\hline $\begin{array}{l}\text { Planting Density } \\
\text { (PD) }\end{array}$ & 5 & 1.91 & 0.1526 & & & \\
\hline Error a & 15 & & & & & \\
\hline Year (Y) & 10 & 301.67 & $<.0001$ & $<.0001$ & $<.0001$ & $<.0001$ \\
\hline $\mathrm{PD} \times \mathrm{Y}$ & 50 & 2.64 & $<.0001$ & 0.0045 & 0.0006 & 0.0066 \\
\hline Error b & 180 & & & & & \\
\hline Mean & & 4864.82 & & & & \\
\hline $\mathrm{CV}(\%)$ & & 17.19 & & & & \\
\hline Planting Density & & Mean & & Ikey & Dun & ett* \\
\hline 1 & & 5369.8 & & A & & \\
\hline 2 & & 5053.3 & & A & & \\
\hline 3 & & 5039.0 & & A & & \\
\hline 5 & & 4917.4 & & A & & \\
\hline 4 & & 4459.3 & & A & & \\
\hline 6 & & 4350.1 & & A & & \\
\hline
\end{tabular}

*Compared to planting density 3 as standard; Greenhouse-Geisser Epsilon: 0.3019; Huynh-Feldt Epsilon: 0.4704; ns: not significant 
Table 2 - Analysis of variance with repeated measures for wet seed weight (WSW, in $\mathrm{kg} \mathrm{plot}^{-1}$ ) assessed in a cacao hybrid mixture evaluated in six planting densities (1980-90).

\begin{tabular}{|c|c|c|c|c|c|c|}
\hline \multirow[b]{2}{*}{ Sources of variation } & \multirow[b]{2}{*}{$\mathrm{df}$} & \multirow[b]{2}{*}{$\mathrm{F}$} & \multicolumn{4}{|c|}{ P value } \\
\hline & & & (univariate $\mathrm{F}$ ) & (G-G adjustment) & (H-F condition) & (multivariate F) \\
\hline Block & 3 & & & & & \\
\hline $\begin{array}{l}\text { Planting Density } \\
\text { (PD) }\end{array}$ & 5 & 2.61 & 0.0688 & & & \\
\hline Error a & 15 & & & & & \\
\hline Year $(Y)$ & 10 & 384.12 & $<.0001$ & $<.0001$ & $<.0001$ & $<.0001$ \\
\hline $\mathrm{PD} \times \mathrm{Y}$ & 50 & 3.29 & $<.0001$ & 0.0010 & $<.0001$ & 0.0044 \\
\hline Error b & 180 & & & & & \\
\hline Mean & & 388.49 & & & & \\
\hline $\mathrm{CV}(\%)$ & & 18.16 & & & & \\
\hline Planting Density & & Mean & & ukey & Dun & ett* \\
\hline 1 & & 437.52 & & A & & \\
\hline 2 & & 412.77 & & A & & \\
\hline 3 & & 402.05 & & A & & \\
\hline 5 & & 375.00 & & A & & \\
\hline 4 & & 359.66 & & A & & \\
\hline 6 & & 343.98 & & A & & \\
\hline
\end{tabular}

*Compared to planting density 3 as standard; Greenhouse-Geisser Epsilon: 0.2746; Huynh-Feldt Epsilon: 0.4190; ns: not significant

Table 3 - Analysis of variance with repeated measures for dry seed weight (DSW, in $\mathrm{kg} \mathrm{plot}^{-1}$ ) assessed in a cacao hybrid mixture evaluated in six planting densities (1980-90).

\begin{tabular}{|c|c|c|c|c|c|c|}
\hline \multirow[b]{2}{*}{ Sources of variation } & \multirow[b]{2}{*}{ df } & \multirow[b]{2}{*}{$\mathrm{F}$} & \multicolumn{4}{|c|}{\begin{tabular}{|l} 
P value \\
\end{tabular}} \\
\hline & & & (univariate F) & (G-G adjustment) & (H-F condition $)$ & (multivariate F) \\
\hline Block & 3 & & & & & \\
\hline $\begin{array}{l}\text { Planting Density } \\
\text { (PD) }\end{array}$ & 5 & 2.61 & 0.0684 & & & \\
\hline Error a & 15 & & & & & \\
\hline Year $(Y)$ & 10 & 382.81 & $<.0001$ & $<.0001$ & $<.0001$ & $<.0001$ \\
\hline PD x Y & 50 & 3.27 & $<.0001$ & 0.0011 & $<.0001$ & 0.0041 \\
\hline Error b & 180 & & & & & \\
\hline Mean & & 155.38 & & & & \\
\hline $\mathrm{CV}(\%)$ & & 18.20 & & & & \\
\hline Planting Density & & Mean & & ukey & Dun & ett* \\
\hline 1 & & 175.02 & & A & $\mathrm{n}$ & \\
\hline 2 & & 165.09 & & A & $\mathrm{n}$ & \\
\hline 3 & & 160.82 & & A & n & \\
\hline 4 & & 150.00 & & A & $\mathrm{n}$ & \\
\hline 5 & & 143.80 & & A & & \\
\hline 6 & & 137.59 & & A & $\mathrm{n}$ & \\
\hline
\end{tabular}

*Compared to planting density 3 as standard; Greenhouse-Geisser Epsilon: 0.2743; Huynh-Feldt Epsilon: 0.4184; ns: not significant 
Table 4 - Estimates of the TNF, WSW and DSW means assessed in a cacao hybrid mixture evaluated in six planting densities during pre- (1980-85) and post-climax (1986-90).

\begin{tabular}{|c|c|c|c|c|c|c|c|c|c|}
\hline \multirow[b]{2}{*}{ Planting Density } & \multicolumn{9}{|c|}{ Pre-climax (1980-85) } \\
\hline & TNF & $\mathrm{T}^{1}$ & $\mathrm{D}^{2 *}$ & WSW & $\mathrm{T}^{1}$ & $\mathrm{D}^{2}$ & DSW & $\mathrm{T}^{1}$ & $\mathrm{D}^{2}$ \\
\hline 1 & 8179.4 & A & ns & 700.54 & $\mathrm{~A}$ & ns & 280.21 & $\mathrm{~A}$ & ns \\
\hline 2 & 7585.0 & A & ns & 656.21 & $\mathrm{AB}$ & ns & 262.50 & $\mathrm{AB}$ & ns \\
\hline 3 & 7600.9 & A & ns & 634.29 & $\mathrm{AB}$ & ns & 253.67 & $\mathrm{AB}$ & ns \\
\hline 4 & 6841.2 & A & ns & 576.00 & $\mathrm{AB}$ & ns & 230.38 & $\mathrm{AB}$ & ns \\
\hline 5 & 6736.1 & A & ns & 544.54 & $\mathrm{~B}$ & ns & 217.83 & $\mathrm{~B}$ & ns \\
\hline 6 & 6490.6 & A & ns & 538.71 & $\mathrm{~B}$ & ns & 215.50 & B & ns \\
\hline \multirow[t]{2}{*}{ Mean } & 7238.8 & & & 608.38 & & & 243.34 & & \\
\hline & \multicolumn{9}{|c|}{ Post-climax (1986-90) } \\
\hline Planting Density & TNF & $\mathrm{T}^{1}$ & $\mathrm{D}^{2}$ & WSW & $\mathrm{T}^{1}$ & $\mathrm{D}^{2}$ & DSW & $\mathrm{T}^{1}$ & $\mathrm{D}^{2}$ \\
\hline 1 & 1998.4 & $\mathrm{AB}$ & ns & 121.90 & $\mathrm{AB}$ & ns & 48.80 & $\mathrm{AB}$ & ns \\
\hline 2 & 2015.1 & $\mathrm{AB}$ & ns & 120.65 & $\mathrm{AB}$ & ns & 48.20 & $\mathrm{AB}$ & ns \\
\hline 3 & 1964.7 & $\mathrm{AB}$ & ns & 123.35 & $\mathrm{AB}$ & ns & 49.40 & $\mathrm{AB}$ & ns \\
\hline 4 & 1601.1 & $\mathrm{~B}$ & ns & 100.05 & $\mathrm{~B}$ & ns & 39.90 & $\mathrm{~B}$ & ns \\
\hline 5 & 2735.1 & A & $* *$ & 171.55 & A & $* *$ & 68.60 & A & $* *$ \\
\hline 6 & 1781.6 & $\mathrm{~B}$ & ns & 110.30 & $\mathrm{~B}$ & ns & 44.10 & $\mathrm{~B}$ & ns \\
\hline Mean & 2015.9 & & & 124.63 & & & 49.83 & & \\
\hline
\end{tabular}

${ }^{\mathrm{T}}$ Tukey test and ${ }^{2}$ Dunnett test; ${ }^{*}$ Compared to planting density 3 as standard; ns: not significant; ** $\mathrm{P}<0.05$

\section{RESUMO}

$\mathrm{O}$ efeito de seis densidades de plantio sobre a produção de um híbrido comercial de cacau, bem como a interação das densidades com os anos, foi investigado. Dados coletados do cultivo por 14 anos (1977-1990) mostraram que é possível otimizar a produção de cacau da região implementando uma alta densidade populacional (2500 e 1736 plantas $\mathrm{ha}^{-1}$ ). Todavia, isto se verificou apenas para a primeira metade do período de cultivo. Na segunda metade, a baixa densidade (1059 plantas $\mathrm{ha}^{-1}$ ) foi superior em produção. Esta mudança na densidade com o passar dos anos foi confirmada pela presença da interação densidades por anos. Alternativas para alcançar elevadas produtividades nos sistemas com altas densidades foram apresentadas e discutidas.

\section{REFERENCES}

Dias, L. A. S. (Ed). (2004), Genetic improvement of cacao. Translation by Abreu-Reichart C. E., Viçosa, M.G., Brazil; aided by the Editor and FAO. EcoPort version by Peter Griffee, FAO. http://ecoport.org/ep?SearchType=earticleViewandea rticleId $=197$ andpage $=-1$ andcheckRequired $=Y$

Dias, L. A. S.; Cruz, C. D. and Carneiro, P. C. S. (2001), Analysis of experiments with repeated measures. Ingenic Newsletter, 6, 29-31.
Dias, L. A. S. and Kageyama, P. Y. (1998). Comparison between multivariate methods applied for the evaluation of genetic divergence in cacao (Theobroma cacao L.). Brazilian Archives of Biology and Technology, 41, 199-206.

Dias, L. A. S.; Marita, J.; Cruz, C. D.; Barros, E. G. and Salomão, T. M. F. (2003a). Genetic distance and its association with heterosis in cacao. Brazilian Archives of Biology and Technology, 46, 339-347.

Dias, L. A. S.; Santos, M. M.; Santos, A. O.; Almeida, C. M. V. C.; Cruz, C. D. and Carneiro, P. C. S. (2000), Effect of planting density on yield and incidence of witches' broom disease in a young plantation of hybrid cacao trees. Experimental Agriculture, 36, 501-508.

Dias, L. A. S.; Souza, C. A. S.; Augusto, S. G.; Siqueira, P. R. and Müller, M. W. (1998), Performance and temporal stability analyses of cacao cultivars in Linhares, Brasil. Plantations, Recherche, Développement, 5, 343-355.

Dias, L. A. S.; Souza, C. A. S.; Augusto, S. G.; Siqueira, P. R. and Müller, M. W. (2003b), Período mínimo de colheita para avaliação de cultivares de cacau em Linhares, ES. Revista Árvore, 27, 495-501.

Freeman, W. G. (1929), Results of cacao research at River State, Trinidad. Tropical Agriculture, 6, 127133.

Kowal, J. M. L. (1959), The effect of spacing on the environment and performance of cacao under Nigeria conditions. Empire Journal of Experimental Agriculture, 27, 27-34. 
Laker, H. A. and Mota, J. W. S. (1990), Witches' broom of cocoa in the State of Rondonia, Brazil: Historical perspectives and present situation. Cocoa Growers' Bulletin, 43, 45-57.

Laker, H. A. (1990), Reactions of cocoa (Theobroma cacao) seedlings and clonal plants to isolates of Crinipellis perniciosa in Trinidad. Tropical Agriculture, 67, 43-48.

Lockwood, G. and Pang, J. T. Y. (1996), Yields of cocoa clones in response to planting density in Malaysia. Experimental Agriculture, 32, 41-47.

Luz, E. D. M. N.; Bezerra, J. L.; Resende, M. L. V. and Oliveira, M. L. (1997), Cacau (Theobroma cacao L.): controle de doenças. In Controle de doenças de plantas: grandes culturas, eds F. X. R. Vale and L. Zambolim). UFV, Departamento de Fitopatologia/Ministério da Agricultura e do Abastecimento, Viçosa/Brasília, vol. 2, pp. 611-649.
SAS Institute (1989), SAS/STAT user's guide, version 6. 4. ed., vol. 2. SAS Institute Inc, Cary.

Steel, R. G. D. and Torrie, J. H. (1980), Principles and Procedures of Statistics. McGraw-Hill, New York.

Wheeler, B. E. J and Mepsted, R. (1982), Pathogenic races of Crinipellis perniciosa, 365-370. In Proceedings of the $8^{\text {th }}$ International Cocoa Research Conference, Cameroon, 1979. London: J de Lafforest and Transla-Inter.

Wood, G. A. R. and Lass, R. A. (1985), Cocoa (Fourth edition). London: Longman.

Received: March 15, 2007;

Revised: March 25, 2008; Accepted: January 30, 2009. 